\title{
Molecular Basis for Global Incidence of Pemphigoid Diseases and Differences in Phenotypes
}

\author{
A. Razzaque Ahmed ${ }^{1 *}$, Sarah Anwar $^{2}$ and Pedro A. Reche ${ }^{3}$ \\ ${ }^{1}$ Department of Dermatology, Center for Blistering Diseases, Tufts University School of Medicine, Boston, \\ MA, United States, 2 Tufts University School of Medicine, Boston, MA, United States, ${ }^{3}$ Department of Immunology \& \\ O2, Faculty of Medicine, University Complutense of Madrid, Madrid, Spain
}

Pemphigoid (Pg) diseases are a group of potentially fatal autoimmune mucocutaneous diseases. They have different clinical phenotypes, involving only the skin or multiple mucous membranes. They occur globally and frequently affect the elderly. The common marker among all variants is the presence of autoantibodies targeting the dermalepidermal or mucosal-submucosal junctions, or basement membrane zone (BMZ). Four target antigens in the BMZ were studied. These included BPAG1, BPAG2 and subunits of $\alpha 6$ and $\beta 4$ human integrins. Our objective was to find a molecular basis for the global incidence of $\mathrm{Pg}$ diseases and a mechanism that will explain the vast differences in clinical phenotypes and outcomes. All the variants of Pg that were analyzed had a statistically significant association with HLA-DQ $\beta 1^{*} 03: 01$ in ten countries on four continents. This explains the reason for global incidence. Prediction models discovered multiple peptides in each of the four antigens that serve as $T$ cell epitopes. These $T$ cell epitopes were shown to bind to HLA-DQ $\beta 1^{\star} 03: 01$. In addition, structure modelling demonstrated the peptideHLA complex bound to the T cell receptor. These autoreactive $T$ cells would stimulate $B$ cells to produce specific anti-BMZ autoantibodies. Anti-BMZ autoantibodies with different specificities will produce different phenotypes, which will account for involvement of different tissues and organs in different molecules. The contribution this study makes is that it provides a molecular basis of why a similar disease occurs in different racial groups. Furthermore, it provides the basis for the production of autoantibodies with different specificities, which resultantly produces different phenotypes.

Keywords: MHC class II genes, DQB1*;03:01, pemphigoid diseases, global incidence, phenotypic presentation, DPP4-inhibitor associated pemphigoid

\section{INTRODUCTION}

Pemphigoid $(\mathrm{Pg})$ is a group of autoimmune blistering diseases that can affect the skin and multiple mucous membranes (1). They can be fatal, difficult to diagnose, and treatment can be delayed. Data presented in this manuscript suggests that they are a good model to study autoimmunity.

The lesions in bullous pemphigoid (BP) are vesicles and bullae of variable sizes, in an acral or generalized distribution (2). In some patients mucous membranes may be involved. The most common cause of death in these patients is opportunistic infection due to prolonged iatrogenic immune suppression (3). BP affects predominantly the elderly, which is of particular relevance as the aging 
population is increasing globally (4). The mortality rate increases with each increasing decade of life (5). BP occurs between 2.4 to 23 cases per million in the general population worldwide (5).

Mucous membrane pemphigoid (MMP) predominantly affects multiple mucosae and not infrequently the skin. As the blisters heal, they cause scarring, which is the reason for its former name, cicatricial pemphigoid. In most patients, this scarring produces sequelae that are catastrophic and severely impact the quality of life $(1,6)$. Of special note are two subsets of MMP, ocular MMP and oral MMP. Other clinical entities such as anti-laminin-332 pemphigoid (7) and anti-p200 pemphigoid (8), are not included in this study. There is a general absence of data on these two disease entities, which is central to the hypothesis of this study.

The most common feature among pemphigoid diseases is that the blisters appear at the junction of the epidermis and dermis or mucosa and submucosa. Using direct immunofluorescence, the immunopathologic features include deposition of $\operatorname{IgG}$ and complement at the dermal-epidermal junction or basement membrane zone (BMZ) in the perilesional tissues (1). This is the standard test for diagnosis. Autoantibodies to BMZ proteins can be detected by indirect immunofluorescence using human skin or monkey esophagus as substrate (9). In some cases, ELISAs have been developed (1). In several studies anti-BMZ autoantibodies have been purified from plasma of patients with active pemphigoid diseases. When these purified human antiBMZ autoantibodies are cultured with human tissue in vitro, they bind to the BMZ, when studied by histology and immunopathology. When injected into laboratory animals, they produce blisters in vivo $(1,10)$. Such studies confirm their role in the pathogenesis. In addition, multiple cells of the immune and inflammatory pathways, play a pivotal and essential role in the phenotypic presentation of pemphigoid diseases.

The pathognomonic and unique feature of MMP is that it causes scarring as it heals, except in the oral cavity (6). Scarring does not occur in BP. In the conjunctiva, the scarring leads to blindness in approximately $25 \%$ of patients (11). In the larynx, abrupt closure can result in sudden asphyxiation (6). Esophageal strictures can cause esophageal rupture and can result in fatal mediastinitis (12). Vaginal involvement can result in severe vaginal stenosis (12). Anal involvement can result in constant fecal leakage and the need for adult diapers for most of the patient's life (12). MMP is more rare with an incidence of 1-2 cases per million (13).

In $\mathrm{BP}$, the anti-BMZ autoantibodies are directed against BP antigen 1 (BPAG1 or BP230) and BP antigen 2 (BPAG2 or $\mathrm{BP} 180)(14,15)$. In a large cohort of patients from Germany, in a recent study, the most frequently targeted antigen was BP180 (15). Their injection produces blisters in the skin of neonatal mice $(16,17)$. In MMP, the antigens are a subunit of human integrins $\beta 4$ and $\alpha 6$. Antibodies from patients' sera against $\beta 4$ produced subepidermal blisters in neonatal mice (18). When normal human oral mucosa was incubated with antibodies to subunit of human $\alpha 6$ integrin from sera of patients with oral pemphigoid, separation of the mucosa from the submucosa has been observed (19).

Earlier studies from our group demonstrated that patients with BP, MMP, and its subsets had a strong correlation with the
HLA-DQ $\beta 1^{\star}$ 03:01 allele, in spite of strikingly different clinical presentations, courses and prognoses (20-22).

Recently, a new group of drugs has been added to the treatment of type II diabetes mellitus, known as dipeptidyl peptidase-4 inhibitors (DPP4-is). Many patients treated with these drugs have been reported to develop pemphigoid (23).

The purpose of this study was to determine the global presence of pemphigoid diseases. Furthermore, to investigate the molecular basis for the global presence and simultaneously to study what mechanisms might explain such striking differences in clinical profiles and clinical outcomes, and the reasons for production of autoantibodies to diverse proteins in the BMZ.

\section{MATERIALS AND METHODS}

PubMed, Embase, and Medline searches were conducted using the following key words: bullous pemphigoid, mucous membrane pemphigoid, cicatricial pemphigoid, oral pemphigoid, BMZ proteins, anti-BMZ antibodies, and HLA genotyping.

\section{Patient Selection}

Inclusion criteria included (i) the presence of the location of the study, (ii) the ethnicity or race of the patients and the control group being identical, (iii) data on HLA genotyping, (iv) clinical profile of patients to confirm the clinical diagnosis, and confirmation of diagnosis by histology and immunopathology.

Exclusion criteria included (i) inadequate or incomplete clinical description of the patients or the control group and/or absence of histology and immunopathology and (ii) presence of inappropriate (age and sex matched) control group.

\section{HLA Class II Genes}

The data available on HLA typing results in patients with BP, MMP, and patients with diabetes mellitus treated with DPP4-i drugs who developed pemphigoid, formed the database for this study. In each study, presence of data on adequate controls was carefully analyzed.

HLA studies were conducted at different centers worldwide. The results were used in the database as provided by the authors. In two studies regarding MMP, data was reported in the studies as allele frequencies and was converted into patient frequencies $(22,24)$. In one study, information regarding controls was absent in the publication (20). This information was provided via written communication by the author.

Statistical significance of the difference in frequency of HLA $\mathrm{DQ} \beta 1^{\star}$ 03:01 between patients and controls was estimated by Chi-square test and Yates' correction (SPSS 27). A p value of less than 0.05 was considered significant.

\section{Identification of T Cell Epitopes in Pemphigoid Antigens}

Autoreactive T cells recognize self-peptide antigens bound to HLA class II (HLA II) molecules. Hence T cell epitopes may be deduced by predicting peptide binding to HLA II molecules (25). In this study, peptide binding to HLA II molecules was assessed at the RANKPEP server (http://imed.med.ucm.es/tools/rankpep.html). 
T cell epitopes within BP180, BP230, human $\beta 4$ integrin, and $\alpha 6$ integrin that are restricted by HLA-DQ7 were predicted. The $\beta$ chain of HLA-DQ7 is $\mathrm{DQ} \beta 1^{*} 03: 01$. For the prediction of the peptide-HLA binding, RANKPEP relies on Position Specific Scoring Matrices (PSSM), which are derived from peptides that are known to bind to HLA molecules. Only those peptides that had a score higher than the Binding Threshold were considered as potential candidates for binding to $\mathrm{DQ} \beta 1^{\star} 03: 01$., as described earlier (26-28).

\section{Generation of Tertiary Structures of Potential T Cell Epitopes Bound to DQ7 (DQß1*03:01)}

The tertiary structure of DQ7 (DQA $\left.1^{\star} 03: 01 / \mathrm{DQ} \beta 1^{\star} 03: 01\right)$ in complex with 15-mer peptide antigens FNWLPPGKPMGYRV, DNVIRKYGDPGSLFG, PAKAIAAVKSGGAVL, and LERIRRSILPYGDSM from integrin $\beta 4$ (AC: NP_000204), integrin $\alpha 6$ isoform a (AC: NP_001073286), dystonin-1 (BPAG1) (AC: NP_899236), and alpha 1 type XII collagen (BPAG2 or BP180) (AC: NP_000485), respectively, were generated by homology modeling after two known tertiary structures of DQ8 (PDB IDs: 1JK8 \& 2NNA) using a standalone version of MODELLER (29). Tertiary structure models were subjected to MODELLER energy optimization methods, selecting the best model upon discrete optimized potential energy (DOPE) scores. Superimposition of tertiary structures and molecular graphic representations were obtained using PyMol Molecular Graphics System, Version 2.0 Schrodinger, LLC.

\section{RESULTS}

\section{HLA Class II Genes in Pg Patients}

Nineteen studies published between 1990 and 2020 were included in this study.

Nine reports that included data on 904 patients with BP were included in this analysis. The studies were from the following countries: Iran (30), Brazil (31), China (32-34), Britain (35), the US (20), Germany (36), and Japan (37), each reporting their native populations (Table $\mathbf{1}$ ).

When the frequency of HLA DQ $\beta 1^{\star} 03: 01$ was collectively compared between BP patients and controls, it was highly statistically significant in the BP patients $(\mathrm{p}<0.00001)$.

In eight reports, MHC class II genes were studied in 335 patients with MMP from the US $(21,22,38)$, UK (39), France $(24,40)$, Germany (41), and Italy (42). When the frequency of $\mathrm{DQ} \beta 1^{\star} 03: 01$ was compared between the patients and the controls, the frequency in the patients was highly statistically significant $(\mathrm{p}<0.00001)$ (Table 2).

In examining data on DPP4i-associated BP, only two studies, one from Japan (43) and one from Finland (44), MHC class II genes were detected, 30 patients in total. When the frequency of DQ $\beta 1^{\star} 03: 01$ was compared between patients and controls, the frequency in the patients was highly statistically significant $(\mathrm{p}<0.00001)$.

These data clearly demonstrate that in many countries that are ethnically different from each other, the clinical profiles are similar.
The MHC class II genes are identical, demonstrating the pivotal role of $\mathrm{DQ} \beta 1^{\star}$ 03:01 being central to the pathogenesis of BP and MMP. Despite this remarkable similarity, patients develop two very distinct clinical profiles with different clinical outcomes. As described below, different peptides within each antigen may be involved in different racial or ethnic groups. Similarly, the presence of different portions of the peptide binding to $\mathrm{DQ} \beta 1^{\star} 03: 01$ may produce a different clinical profile, accounting for involvement of different tissues or organs.

\section{Putative T Cell Epitopes in Pg Antigens}

Molecular analysis of possible antigen binding sites on HLADQ7 (DQ $\left.\beta 1^{\star} 03: 01\right)$ were done by a computer model. The computer model used identified peptides within the four antigens known to be pathogenic in pemphigoid diseases, that potentially could be $\mathrm{T}$ cell epitopes. Identified were 14 sites within BP180, 30 sites within BP230 14 sites within $\beta 4$ integrin, and 7 sites within $\alpha 6$ integrin (Figure 1).

\section{T Cell Receptor Recognition of T Cell Epitopes in Pg Antigens}

$\mathrm{T}$ cell epitopes (generated by computer modeling) within pemphigoid antigens binding to $\mathrm{DQ} \beta 1^{\star} 03: 01$ were modeled for binding to $\mathrm{T}$ cell receptor. The graphic representation of this binding is presented in Figure 2. The molecular surface of DQ7 $\left(\mathrm{DQA} 1^{\star} 03: 01 / \mathrm{DQ} \beta 1^{\star} 03: 01\right)$ in complex with peptide antigen from $\beta 4$ integrin (Panel A), $\alpha 6$ integrin (Panel B), BPAG1 (Panel C), and BPAG2 (Panel D). The amino acid sequence of one of the potential peptides that serves as an antigen, is shown over the molecular surface of DQ7 (Figure 2). These superimposed peptides are recognized the $\mathrm{T}$ cell receptor (TCR). The TCR was positioned after the superimposition of the tertiary structure of the models that in PDB 5KS9, corresponding to HLA-DQ8 with a bound glia- $\alpha 1$ peptide in complex with a TCR. Tertiary structures of peptide-DQ7 complexes were obtained by homology modeling (Figure 3). Superimposition of tertiary structures and molecular graphic representations were obtained using PyMol Molecular Graphics System, Version 2.0 Schrodinger, LLC.

\section{DISCUSSION}

In this study, we have demonstrated that the association of $\mathrm{BP}$ with $\mathrm{DQ} \beta 1^{\star} 03: 01$ has been observed in several countries spanning four continents (Figure 4). This confirms that the association is global and crosses racial and ethnic lines. Likewise, the association of MMP with $\mathrm{DQ} \beta 1^{\star} 03: 01$ is multi-national, although the studies have been done predominantly on Caucasian patients in the US, UK, and Europe. The lack of studies from Asia and Africa may in part, be due to lack of diagnostic facilities and/or availability of HLA typing laboratories. Patients with BP and MMP from both continents have been seen at the Center for Blistering Diseases. While there was no study from Australia, Pg disease must be prevalent, since $85 \%$ of the population is Caucasian of European descent (45). 
TABLE 1 | HLA DQB1*03:01 allele frequencies in bullous pemphigoid.

\begin{tabular}{|c|c|c|c|c|c|c|c|c|c|c|}
\hline Author & $\begin{array}{c}\text { Journal \& } \\
\text { Year }\end{array}$ & $\begin{array}{l}\text { No. of } \\
\text { pts }\end{array}$ & $\begin{array}{l}\text { No. of alleles } \\
{ }^{\star} 0301\end{array}$ & $\begin{array}{c}\text { Pt allele } \\
\text { frequency (\%) }\end{array}$ & $\begin{array}{l}\text { No. of } \\
\text { controls }\end{array}$ & $\begin{array}{c}\text { No. of alleles } \\
{ }^{\star} 0301\end{array}$ & $\begin{array}{l}\text { Control allele } \\
\text { frequency }\end{array}$ & Countries & Race & $p$ value \\
\hline Esmaili & |JI. 2013 & 50 & 36 & 36 & 180 & 85 & 23.6 & Iran & Caucasian & 0.02 \\
\hline Chagury & $\begin{array}{l}\text { Ann Dermatol. } \\
2018\end{array}$ & 17 & 13 & 38.2 & 297 & 84 & 14.1 & Brazil & $\begin{array}{l}10 \text { white, } 6 \text { mixed, } \\
1 \text { black }\end{array}$ & $\begin{array}{c}3.72 \times \\
10-4\end{array}$ \\
\hline Fang & JDS. 2017 & 105 & 59 & 28.1 & 420 & 158 & 18.81 & China & Asian & 0.003 \\
\hline Sun & JID. 2018 & 575 & 326 & 28.5 & 976 & 390 & 20 & China & Asian & $\begin{array}{c}1.27 x \\
10-7\end{array}$ \\
\hline Banfield & BJD. 1998 & 73 & 39 & 26.7 & 604 & 189 & 15.6 & Britain & Caucasian & $<0.01$ \\
\hline Delgado & $\begin{array}{l}\text { PNAS USA. } \\
1996\end{array}$ & 21 & 15 & 35.7 & 109 & 35 & 16.05 & US & Caucasian & 0.005 \\
\hline Budinger & JCl. 1998 & 15 & 13 & 43.3 & 24 & 11 & 22.9 & Germany & Caucasian & 0.05 \\
\hline Okazaki & $\begin{array}{l}\text { J Dermatol. } \\
2000\end{array}$ & 23 & 6 & 13.0 & 525 & 101 & 9.62 & Japan & Asian & NS \\
\hline Gao & CED. 2002 & 25 & 15 & 30.72 & 57 & 30 & 26.25 & China & Asian & NS \\
\hline
\end{tabular}

One of the most recent advances in the treatment of type II diabetes mellitus is the use of DPP-4i drugs. The incidence of BP in these patients is significant (23). There are many studies that document this association, but most do not contain data on HLA typing. The two reports included in this study, from Japan and Finland, demonstrate a strong association with DPP-4i-associated BP and HLA DQ $\beta 1^{*} 03: 01(43,44)$. These observations would suggest that in all likelihood, this association is also multi-national and global.

The HLA DQ $\beta 1^{\star} 03: 01$ allele was not associated with pemphigoid diseases in two studies from Japan and China, conducted in 2000 and 2002 respectively $(32,37)$. However, subsequent studies from China confirmed this association to be statistically significant $(33,34)$. In the studies lacking this association, the absence of statistical significance could be due to the high frequency of the $\mathrm{DQ} \beta 1^{\star} 03: 01$ allele in the control population. In these studies, age or sex-matched controls were not used. Critical analysis of the data demonstrated that the female to male ratio was 2:1 and the majority of patients were greater than 72 years of age at the time of the onset of the diseases. Clearly, these two parameters were not present in the control population. This might in part provide an explanation for the lack of the association.

Sun et al. stratified BP patients with the HLA DQ $\beta 1^{\star} 03: 01$ allele in the Han Chinese population into groups based on the presence of antibodies. As expected, more patients demonstrated antibodies directed against BP180 than BP230. Out of 575 patients total, $94.7 \%$ were BP180-positive and $45.6 \%$ were BP230-positive. Notably, the authors observed a significant difference in the frequency of $\mathrm{DQ} \beta 1^{\star} 03: 01$ between the BP180 and BP230 groups. Both groups were significantly associated with the $\mathrm{DQ} \beta 1^{*} 03: 01$ allele, but this association was much stronger for the BP180-positive group $\left(\mathrm{p}=5.65 \times 10^{-3}\right)(33)$.

Autoreactive $\mathrm{T}$ cell responses to $\mathrm{BP} 180$ have been investigated in $\mathrm{BP}$ patients. With regards to the $\mathrm{DQ} \beta 1^{\star} 03: 01$ allele, Budinger et al. observed proliferative $\mathrm{T}$ cell responses to BP180 were $\mathrm{DQ} \beta 1^{\star} 03: 01$ restricted (36).

TABLE 2 | HLA DQB1*03:01 patient frequencies in mucous membrane pemphigoid.

\begin{tabular}{|c|c|c|c|c|c|c|c|c|c|c|c|}
\hline Subset & Author & $\begin{array}{c}\text { Journal \& } \\
\text { Year }\end{array}$ & No. of pts & $\begin{array}{c}\text { No. pts DQB1 } \\
{ }^{\star} 0301\end{array}$ & Percent & $\begin{array}{c}\text { No. of } \\
\text { controls }\end{array}$ & $\begin{array}{l}\text { No. controls } \\
{ }^{*} 0301\end{array}$ & Percent & Countries & Race & p value \\
\hline MMP & Hubner & Eye. 2018 & 39 & 31 & 79.5 & 39 & 13 & 33.3 & $\begin{array}{l}\text { Germany, } \\
\text { UK }\end{array}$ & Caucasian & 0.00009 \\
\hline MMP & Setterfield & BJD. 2001 & 128 & 97 & 75.8 & 177 & 53 & 29.9 & France & Caucasian & $\begin{array}{c}<1.0 x \\
10-8\end{array}$ \\
\hline MMP & Drouet & EJD. 1998 & 25 & 20 & 80 & 106 & 46 & 43.4 & France & Caucasian & $<0.001$ \\
\hline OCP & Chan & JID. 1997 & 21 & 16 & 76.2 & 42 & 14 & 33 & US & Caucasian & $<0.005$ \\
\hline $\mathrm{OCP}$ & Ahmed & $\begin{array}{l}\text { PNAS USA. } \\
1991\end{array}$ & $\begin{array}{c}23 \text { haploty } \\
\text { pes }\end{array}$ & 20 haploty pes & 87.0 & $\begin{array}{c}46 \\
\text { haplotyp es }\end{array}$ & 23 haplotyp es & 50 & US & Caucasian & 0.003 \\
\hline OCP & Yunis & $\begin{array}{l}\text { PNAS USA. } \\
1994\end{array}$ & 17 & 13 & 76.5 & 65 & 22 & 33.8 & US & Caucasian & 0.002 \\
\hline OP & Yunis & $\begin{array}{l}\text { PNAS USA. } \\
1994\end{array}$ & 22 & 15 & 68.2 & 65 & 22 & 33.8 & US & Caucasian & $<0.001$ \\
\hline OP & Chan & JID. 1997 & 22 & 15 & 68.2 & 42 & 14 & 33 & US & Caucasian & $<0.025$ \\
\hline $\begin{array}{l}\text { MMP } \\
\text { (mainly OP) }\end{array}$ & Carrozzo & BJD. 2001 & 28 & 27 & 96.4 & 97 & 47 & 48.5 & Italy & Caucasian & 0.0001 \\
\hline $\begin{array}{l}\text { MMP } \\
\text { (mainly OP) }\end{array}$ & Walton & $\begin{array}{l}\text { J Oral Pathol. } \\
2020\end{array}$ & 15 & 11 & 73.3 & 10.000 & 3800 & 38 & UK & Caucasian & 0.005 \\
\hline
\end{tabular}



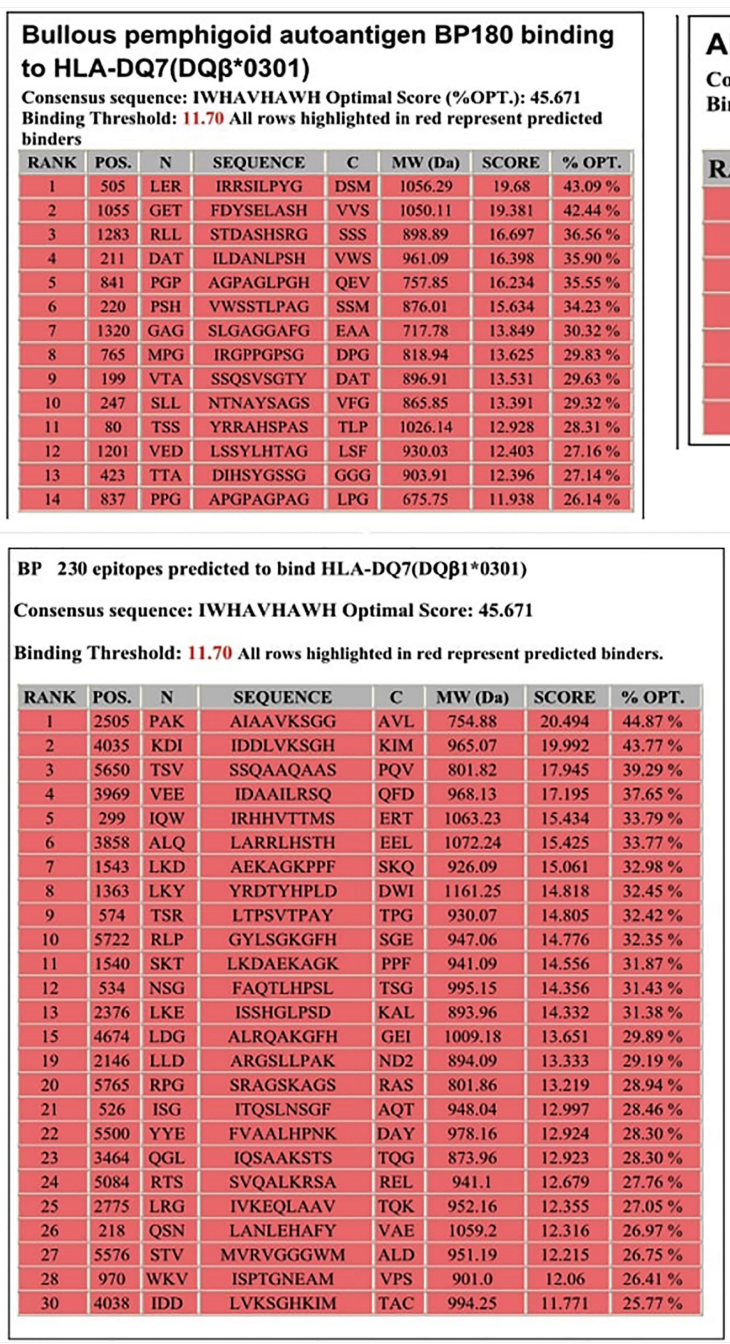

\section{Alpha 6 Integrin binding to DQ7(DQ $\left.\beta^{\star} 0301\right)$}

Consensus sequence: IWHAVHAWH Optimal Score: $\mathbf{4 5 . 6 7 1}$

Binding Threshold: 11.70 All rows highlighted in red represent predicted binders

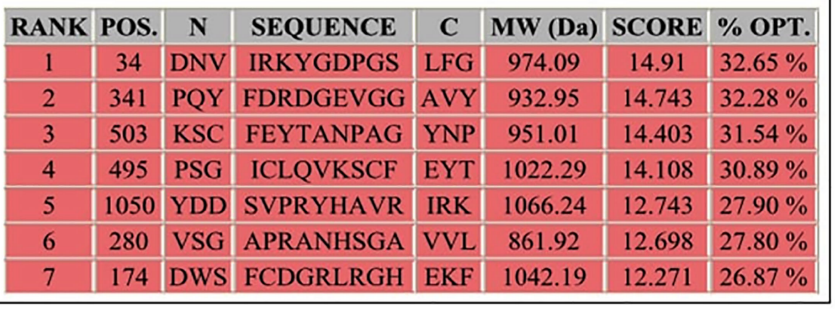

FIGURE 1 | Potential HLA-DQ7 (DQ $\left.\beta 1^{*} 03: 01\right)$-binding peptides in BPAG1, BPAG2, human $\beta 4$ integrin, and human $\alpha 6$ integrin. Obtained from our previous publication. Autoimmunity Reviews 2011;11:40-47. With permission of the editor.

The HLA DQ $\beta 1^{\star}$ 03:01 allele has been associated with other conditions. Statistically significant associations between the $\mathrm{DQ} \beta 1^{\star}$ 03:01 allele have been observed in patients with erythema multiforme, cutaneous melanoma, gastric adenocarcinoma, and cervical cancer (46-49). BP has been associated with various neurological diseases, such as multiple sclerosis, Parkinson's disease, dementia, and epilepsy (50). However, a statistically significant association between HLA DQ $\beta 1^{\star} 03: 01$ has been observed only in multiple sclerosis patients in Europe, Sardinia, Spain, Korea, and Kuwait (51). None of the other neurological diseases associated with BP have a similar HLA association.

Preliminary data presented in this study demonstrates that many of those patients with diabetes mellitus treated with DPP4i drugs who developed BP were carrying the HLA-DQ $\beta 1^{\star}$ 03:01 allele of MHC class II genes. It is entirely possible that this provided enhanced susceptibility to develop BP. These early observations warrant further detailed studies.
Pemphigoid gestationis (HG) a rare autoimmune blistering skin disease that is associated only with pregnancy (52). HG was not included in this review as it is a separate disease entity and does not share the same HLA associations (53-55).

In this study, using a computer model, we identified several peptides in BP180, BP230, and human $\beta 4$ and $\alpha 6$ integrins that could bind to the $\mathrm{T}$ cell receptor. There is data that demonstrates that such models are effective in their prediction and are similar to in vitro models (56). Most studies have concentrated on the NC16A domain of BP180 in the process of generating pemphigoid specific autoreactive $\mathrm{T}$ cells $(57,58)$. Researchers have discovered that peptides other than those in the NC16A domain for BP180 and other peptides in BP230 can also be involved in autoreactive T cells in pemphigoid $(15,36)$. Studies showed that $\mathrm{T}$ cells react with the entire peptide and with sequences 490-534 and 507-534 $(57,58)$. The computer model in this study predicted that sequence of amino acids 505-513 in 
A

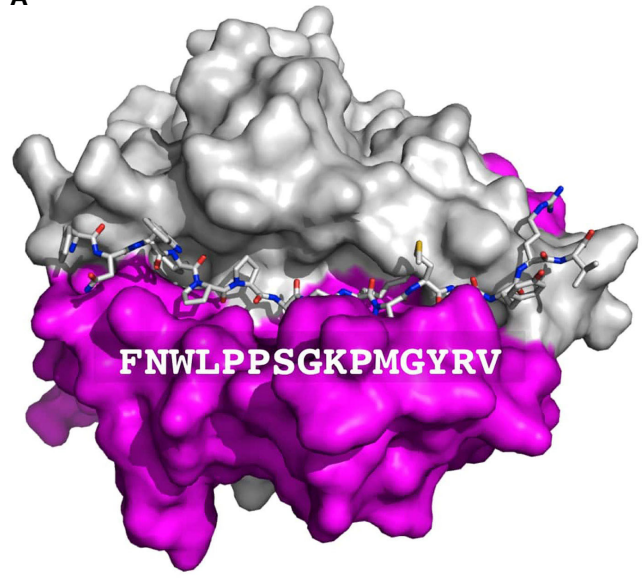

C

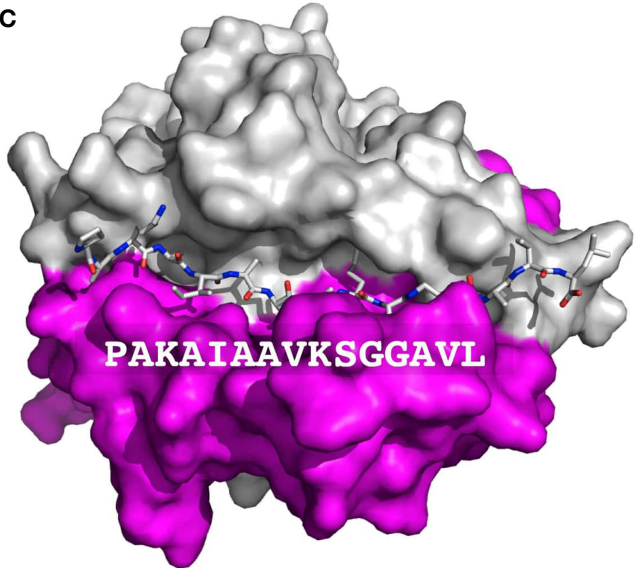

B

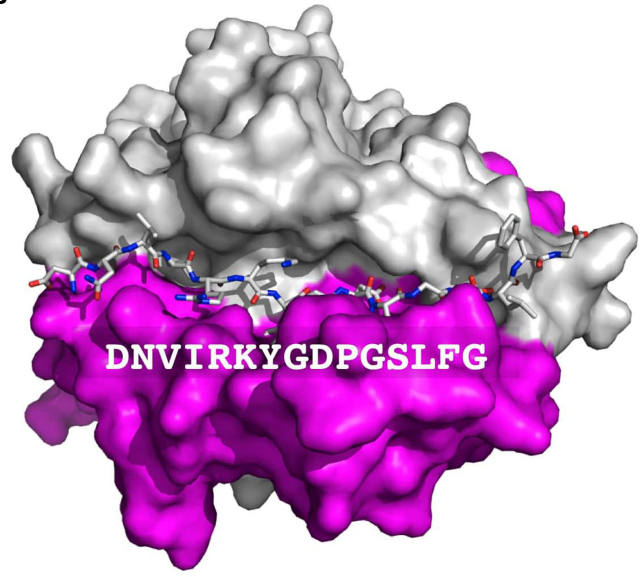

D

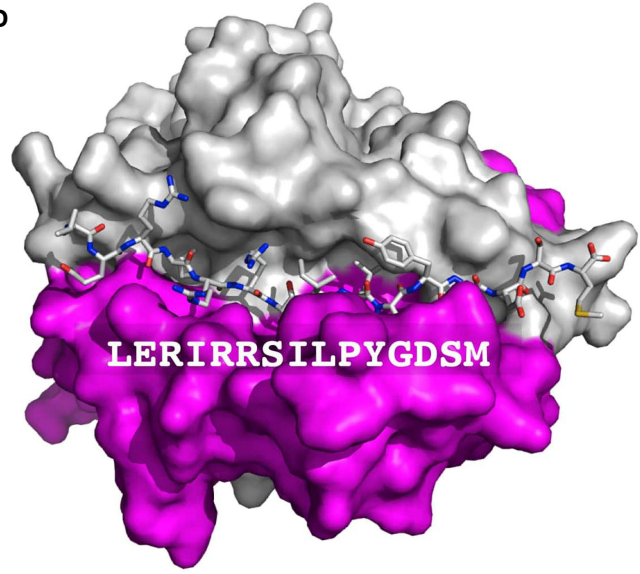

FIGURE 2 | Presentation of BP autoantigens by DQ7. Figure shows a TCR view of the molecular surface of DQ7 (HLA-DQA $\left.1^{*} 03: 01 / H L A-D Q \beta 1^{*} 03: 01\right)$ in complex with peptide antigens, shown as sticks, from Integrin $\beta 4$ (A), Integrin $\alpha 6$ isoform a (B), Dystonin-1or BPAG1 (C), and alpha 1 type XII Collagen (BPAG2 or BP180) (D). The amino sequence of each of peptide is shown over the molecular surface renderings. In these representations, the $\alpha$ and $\beta$ chains of DQ7 are colored in purple and grey, respectively. Tertiary structures of peptide-DQ7 complexes were obtained by homology modeling (details in Methods).

BP180 and others can be putative epitopes for producing autoreactive $\mathrm{T}$ cells. Using a Baculovirus system, investigators identified peptides within the NC16A domain and outside this domain that functioned as $\mathrm{T}$ cell epitopes in the in vitro system. These reported peptides were also present in the computer models in this study. Likewise, studies using in vitro systems identified T cell epitopes in BP230 (15). Similar peptides were identified in the computer model in this study. T cell epitopes in human $\beta 4$ and $\alpha 6$ integrins have not been identified or described. We anticipate that when such in vitro studies become available, they will have significant homology to peptides generated by the computer model. Collectively these studies strongly suggest that peptides generated by the computer model, as potential $\mathrm{T}$ cell epitopes, are similar to the in vitro studies and are therefore relevant and useful.

Using a computer-based model, we demonstrate a representation of how peptides from BP180, BP230, $\beta 4$ integrin, and $\alpha 6$ integrin can be $\mathrm{T}$ cell epitopes presented by DQ7
(Figure 2). These peptides are known to have a capacity to bind to $\mathrm{DQ} \beta 1^{\star} 03: 01$. Further, we demonstrate by a computer model how four different peptides selected from each antigen can be presented to the $\mathrm{T}$ cell receptor (TCR) (Figure 3). The specific autoreactive $\mathrm{CD}^{+}{ }^{+} \mathrm{T}$ cells will enable these cells to engage B cells and provide the necessary help for autoantibody production. Thus, DQ7 alone could promote the production of antibodies to four antigens in the BMZ. Consequently, the anti-BMZ autoantibodies produced will have four different specificities. These anti-BMZ autoantibodies will resultantly produce four or more different clinical phenotypes, which involve different tissue(s) or organ(s).

In our hypothesis, we modeled the tertiary structure of DQ7 in complex with selected peptides. Selected antigens were those with the largest binding scores. HLA molecules contain $\alpha$ and $\beta$ chains. The $\beta$ chain of DQ7 is HLA DQ $\beta 1^{\star} 03: 01$, which pairs with different $\alpha$ chains. In the model we chose HLA DQA1*03:01 because it is the one that pairs most frequently with $\mathrm{DQ} \beta 1^{\star}$ 03:01 (37). 


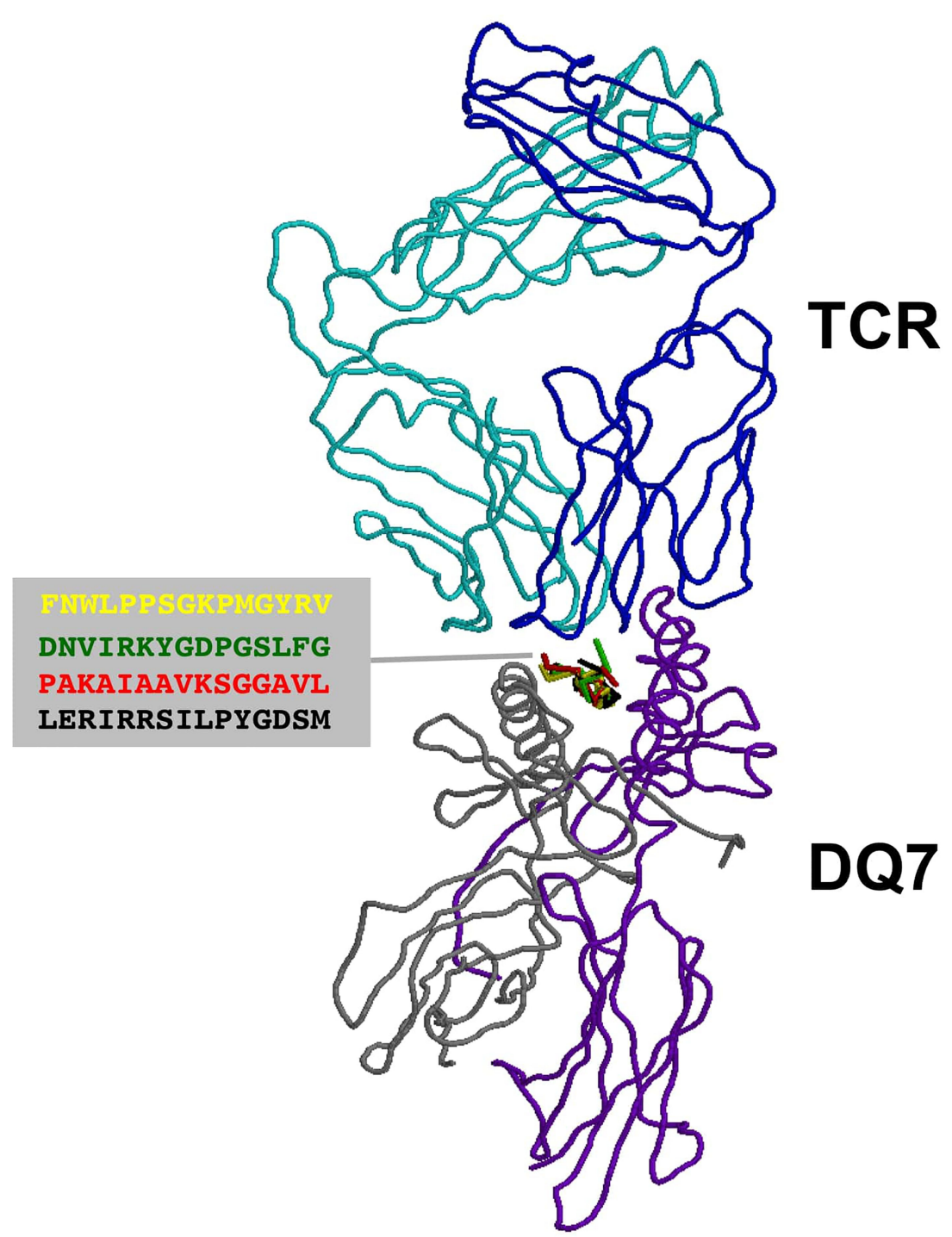

FIGURE 3 | TCR recognition of autoantigens presented by DQ7. Figure shows a ribbon rendering of DQ7 with bound superimposed BP peptide antigens, being recognized by a TCR. BP peptide antigens are colored in yellow (FNWLPPGKPMGYRV), green (DNVIRKYGDPGSLFG), red (PAKAIAAVKSGGAVL) and black (LERIRRSILPYGDSM), respectively. DQ7 $\alpha$ and $\beta$ chains are colored in purple and grey, respectively, while the $\alpha$ and $\beta$ chains of the TCR are shown in cyan and blue, respectively. The TCR was positioned after superimposing the tertiary structure of DQ7 models with that in PDB 5KS9 corresponding to HLA-DQ8 with a bound glia- $\alpha 1$ peptide in complex with a TCR. Tertiary structures of peptide-DQ7 complexes were obtained by homology modeling (details in Methods) and superimposition of tertiary structures and molecular graphic representations were obtained using PyMol Molecular Graphics System, Version 2.0 Schrödinger, LLC.

These computer models, in part, provide the molecular basis for two sets of clinical observation. First, the worldwide occurrence of an autoimmune autoantibody mediated disease with similar clinical presentation. The available data on MHC class II genes, molecular analysis of the four antigens, and the computer model used for this analysis. Second, the selective involvement of specific tissues or organs in the different subsets of pemphigoid diseases. These could in part be due to tissue or organ specific anti-BMZ autoantibodies.

The epidemiology of several autoimmune diseases have been studied and indicate their global occurrence. Some of these are rheumatoid arthritis, systemic lupus erythematosus, systemic sclerosis, myasthenia gravis, and immune thrombocytopenic purpura (ITP) (59-63). The pathogenic mechanisms have been best studied in rheumatoid arthritis and (ITP) $(64,65)$. In some of these diseases, such as rheumatoid arthritis, HLA associations have been described. However, there are variations in the association between different continents and ethnic groups (66).

In this study, we do not provide data to demonstrate which peptide could be used in which ethnic or racial group or which peptide is associated with which organ or tissue involvement. Nonetheless, identification of potential $\mathrm{T}$ cell epitopes in these 


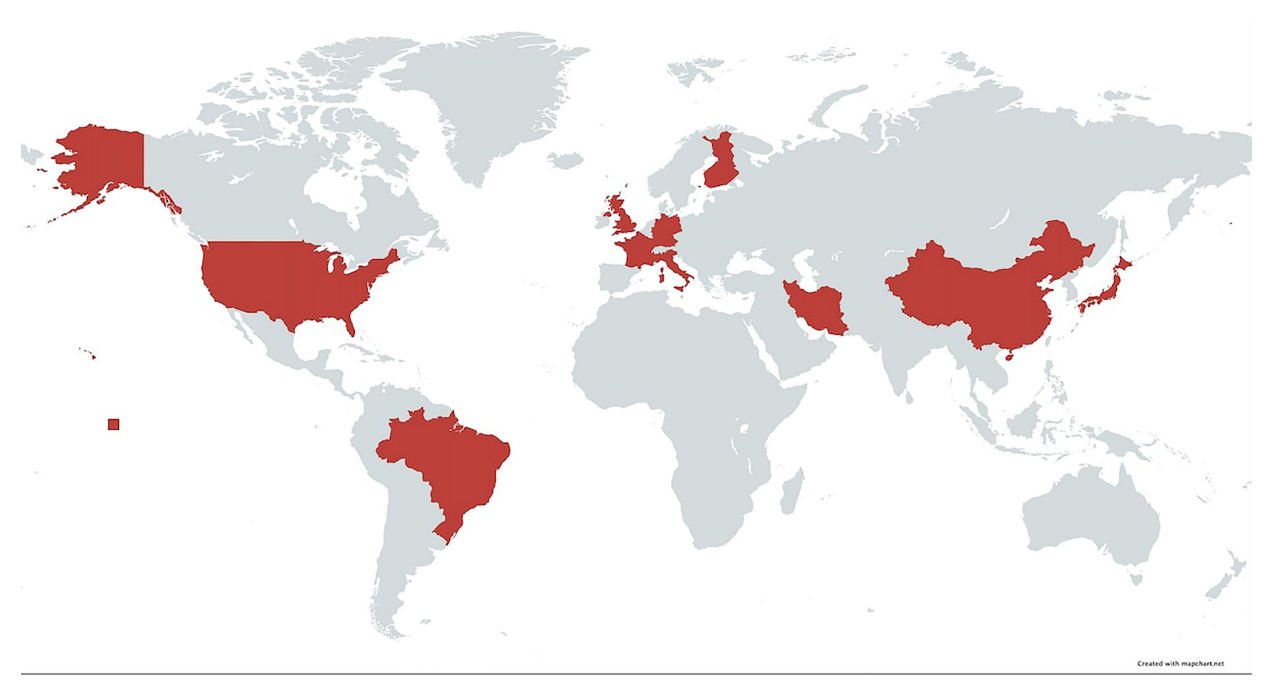

FIGURE 4 | Map of the world highlighting area in which HLA studies have been done on native populations. In these countries, patients with pemphigoid diseases had a strong association with HLA-DQ $\beta 1^{*} 03: 01$.

four antigens associated with BP, MMP, and its clinical variants, could be potentially very beneficial for in vitro studies and clinical correlation. Among other advances in immunopathogenesis, these models could assist in producing disease specific, race specific, targeted therapies.

\section{AUTHOR CONTRIBUTIONS}

The original concept and design of the study was made by AA. The potential peptides in the four antigens that can serve as

\section{REFERENCES}

1. Schmidt E, Zillikens D. Pemphigoid Diseases. Lancet Lond Engl (2013) 381:320-32. doi: 10.1016/S0140-6736(12)61140-4

2. Nousari HC, Anhalt GJ. Pemphigus and Bullous Pemphigoid. Lancet Lond Engl (1999) 354:667-72. doi: 10.1016/S0140-6736(99)03007-X

3. Phoon YW, Fook-Chong SMC, Koh HY, Thirumoorthy T, Pang SM, Lee HY. Infectious Complications in Bullous Pemphigoid: An Analysis of Risk Factors. J Am Acad Dermatol (2015) 72:834-9. doi: 10.1016/j.jaad.2015.01.029

4. Centers for Disease Control and Prevention (CDC). Trends in Aging-United States and Worldwide. MMWR Morb Mortal Wkly Rep (2003) 52:101-104, 106.

5. Kridin K, Ludwig RJ. The Growing Incidence of Bullous Pemphigoid: Overview and Potential Explanations. Front Med (2018) 5:220. doi: 10.3389/fmed. 2018.00220

6. Chan LS, Ahmed AR, Anhalt GJ, Bernauer W, Cooper KD, Elder MJ, et al. The First International Consensus on Mucous Membrane Pemphigoid: Definition, Diagnostic Criteria, Pathogenic Factors, Medical Treatment, and Prognostic Indicators. Arch Dermatol (2002) 138:370-9. doi: 10.1001/ archderm.138.3.370

7. Chiorean R, Danescu S, Virtic O, Mustafa MB, Baican A, Lischka A, et al. Molecular Diagnosis of Anti-Laminin 332 (Epiligrin) Mucous Membrane Pemphigoid. Orphanet J Rare Dis (2018) 13:111. doi: 10.1186/s13023-018-0855-x

8. Kridin K, Ahmed AR. Anti-P200 Pemphigoid: A Systematic Review. Front Immunol (2019) 10:2466. doi: 10.3389/fimmu.2019.02466 molecules presented to $\mathrm{T}$ cell receptors was done by $\mathrm{PR}$. The latest computer analysis of binding of peptides to the $\mathrm{T}$ cell receptor was done by PR. SA performed a detailed literature search for all the studies on the MHC Class II genes in pemphigoid diseases. The manuscript was read and edited by all three authors.

\section{FUNDING}

This study in part was supported by an unrestricted research grant from the Dysimmune Diseases Foundation.

9. Sami N, Yeh SW, Ahmed AR. Blistering Diseases in the Elderly: Diagnosis and Treatment. Dermatol Clin (2004) 22:73-86. doi: 10.1016/s0733-8635(03)00116-5

10. Hammers CM, Stanley JR. Mechanisms of Disease: Pemphigus and Bullous Pemphigoid. Annu Rev Pathol (2016) 11:175-97. doi: 10.1146/annurevpathol-012615-044313

11. Schonberg S, Stokkermans TJ. “Ocular Pemphigoid”. In: StatPearls. Treasure Island (FL): StatPearls Publishing. Available at: http://www.ncbi.nlm.nih.gov/ books/NBK526100/ (Accessed March 1, 2021).

12. Fleming TE, Korman NJ. Cicatricial Pemphigoid. J Am Acad Dermatol (2000) 43:571-591; quiz 591-594. doi: 10.1067/mjd.2000.107248

13. Xu H-H, Werth VP, Parisi E, Sollecito TP. Mucous Membrane Pemphigoid. Dent Clin North Am (2013) 57:611-30. doi: 10.1016/j.cden.2013.07.003

14. Bernard P, Antonicelli F. Bullous Pemphigoid: A Review of its Diagnosis, Associations and Treatment. Am J Clin Dermatol (2017) 18:513-28. doi: 10.1007/ s40257-017-0264-2

15. Van Beek N, Kridin K, Bühler E, Kochan AS, Ständer S, Ludwig RJ, et al. Evaluation of Site- and Autoantigen-Specific Characteristics of Mucous Membrane Pemphigoid. JAMA Dermatol (2021). doi: 10.1001/jamadermatol.2021.4773

16. Shih Y-C, Wang B, Yuan H, Zheng J, Pan M. Role of BP230 Autoantibodies in Bullous Pemphigoid. J Dermatol (2020) 47:317-26. doi: 10.1111/13468138.15251

17. Makita E, Matsuzaki Y, Fukui T, Matsui A, Minakawa S, Nakano H, et al. Autoantibodies to BPAGle Trigger Experimental Bullous Pemphigoid in Mice. J Invest Dermatol (2020) 141(5):1167-76.e3. doi: 10.1016/j.jid.2020.08.031 
18. Rashid KA, Foster CS, Ahmed AR. Identification of Epitopes Within Integrin $\beta 4$ for Binding of Auto-Antibodies in Ocular Cicatricial and Mucous Membrane Pemphigoid: Preliminary Report. Invest Ophthalmol Vis Sci (2013) 54:7707-16. doi: 10.1167/iovs.12-11404

19. Rashid KA, Stern JNH, Ahmed AR. Identification of an Epitope Within Human Integrin Alpha 6 Subunit for the Binding of Autoantibody and its Role in Basement Membrane Separation in Oral Pemphigoid. J Immunol Baltim Md 1950 (2006) 176:1968-77. doi: 10.4049/jimmunol.176.3.1968

20. Delgado JC, Turbay D, Yunis EJ, Yunis JJ, Morton ED, Bhol K, et al. A Common Major Histocompatibility Complex Class II Allele HLA-DQB1* 0301 is Present in Clinical Variants of Pemphigoid. Proc Natl Acad Sci USA (1996) 93:8569-71. doi: 10.1073/pnas.93.16.8569

21. Yunis JJ, Mobini N, Yunis EJ, Alper CA, Deulofeut R, Rodriguez A, et al. Common Major Histocompatibility Complex Class II Markers in Clinical Variants of Cicatricial Pemphigoid. Proc Natl Acad Sci USA (1994) 91:774751. doi: 10.1073/pnas.91.16.7747

22. Ahmed AR, Foster S, Zaltas M, Notani G, Awdeh Z, Alper CA, et al. Association of DQw7 (DQB1*0301) With Ocular Cicatricial Pemphigoid. Proc Natl Acad Sci USA (1991) 88:11579-82. doi: 10.1073/pnas.88.24.11579

23. Tasanen K, Varpuluoma O, Nishie W. Dipeptidyl Peptidase-4 InhibitorAssociated Bullous Pemphigoid. Front Immunol (2019) 10:1238. doi: 10.3389/ fimmu.2019.01238

24. Drouet M, Delpuget-Bertin N, Vaillant L, Chauchaix S, Boulanger MD, Bonnetblanc JM, et al. HLA-DRB1 and HLA-DQB1 Genes in Susceptibility and Resistance to Cicatricial Pemphigoid in French Caucasians. Eur J Dermatol EJD (1998) 8:330-3.

25. Lafuente EM, Reche PA. Prediction of MHC-Peptide Binding: A Systematic and Comprehensive Overview. Curr Pharm Des (2009) 15:3209-20. doi: 10.2174/138161209789105162

26. Reche PA, Glutting J-P, Reinherz EL. Prediction of MHC Class I Binding Peptides Using Profile Motifs. Hum Immunol (2002) 63:701-9. doi: 10.1016/ s0198-8859(02)00432-9

27. Reche PA, Glutting J-P, Zhang H, Reinherz EL. Enhancement to the RANKPEP Resource for the Prediction of Peptide Binding to MHC Molecules Using Profiles. Immunogenetics (2004) 56:405-19. doi: 10.1007/ s00251-004-0709-7

28. Reche PA, Keskin DB, Hussey RE, Ancuta P, Gabuzda D, Reinherz EL. Elicitation From Virus-Naive Individuals of Cytotoxic T Lymphocytes Directed Against Conserved HIV-1 Epitopes. Med Immunol Lond Engl (2006) 5:1. doi: 10.1186/1476-9433-5-1

29. Webb B, Sali A. Protein Structure Modeling With MODELLER. Methods Mol Biol Clifton NJ (2014) 1137:1-15. doi: 10.1007/978-1-4939-0366-5_1

30. Esmaili N, Mortazavi H, Chams-Davatchi C, Daneshpazhooh M, Damavandi MR, Aryanian Z, et al. Association Between HLA-DQB1*03:01 and Bullous Pemphigoid in Iranian Patients. Iran J Immunol IJI (2013) 10:1-9.

31. Chagury AA, Sennes LU, Gil JM, Kalil J, Rodrigues H, Rosales CB, et al. HLA$\mathrm{C}^{\star} 17, \mathrm{DQB} 1^{\star} 03: 01, \mathrm{DQA1}{ }^{\star} 01: 03$ and $\mathrm{DQA1}{ }^{*} 05: 05$ Alleles Associated to Bullous Pemphigoid in Brazilian Population. Ann Dermatol (2018) 30:8-12. doi: 10.5021/ad.2018.30.1.8

32. Gao X-H, Winsey S, Li G, Barnardo M, Zhu X-J, Chen H-D, et al. HLA-DR and DQ Polymorphisms in Bullous Pemphigoid From Northern China. Clin Exp Dermatol (2002) 27:319-21. doi: 10.1046/j.1365-2230.2002.01037.x

33. Sun Y, Liu H, Wang Z, Fu X, Wang C, Mi Z, et al. The HLA-DQB1*03:01 Is Associated With Bullous Pemphigoid in the Han Chinese Population. J Invest Dermatol (2018) 138:1874-7. doi: 10.1016/j.jid.2018.02.021

34. Fang H, Shen S, Zheng X, Dang E, Zhang J, Shao S, et al. Association of HLA Class I and Class II Alleles With Bullous Pemphigoid in Chinese Hans. J Dermatol Sci (2018) 89:258-62. doi: 10.1016/j.jdermsci.2017.11.014

35. Banfield CC, Wojnarowska F, Allen J, George S, Venning VA, Welsh KI. The Association of HLA-DQ7 With Bullous Pemphigoid is Restricted to Men. $\mathrm{Br} J$ Dermatol (1998) 138:1085-90. doi: 10.1046/j.1365-2133.1998.02350.x

36. Büdinger L, Borradori L, Yee C, Eming R, Ferencik S, Grosse-Wilde H, et al. Identification and Characterization of Autoreactive $\mathrm{T}$ Cell Responses to Bullous Pemphigoid Antigen 2 in Patients and Healthy Controls. J Clin Invest (1998) 102:2082-9. doi: 10.1172/JCI3335

37. Okazaki A, Miyagawa S, Yamashina Y, Kitamura W, Shirai T. Polymorphisms of HLA-DR and -DQ Genes in Japanese Patients With Bullous Pemphigoid. J Dermatol (2000) 27:149-56. doi: 10.1111/j.1346-8138.2000.tb02141.x
38. Chan LS, Hammerberg C, Cooper KD. Significantly Increased Occurrence of HLA-DQB1 ${ }^{\star} 0301$ Allele in Patients With Ocular Cicatricial Pemphigoid. J Invest Dermatol (1997) 108:129-32. doi: 10.1111/1523-1747.ep12332352

39. Walton R, Robinson M, Carrozzo M. A Service Evaluation of the Diagnostic Testing for Mucous Membrane Pemphigoid in a UK Oral Medicine Unit. J Oral Pathol Med Off Publ Int Assoc Oral Pathol Am Acad Oral Pathol (2020) 49:687-92. doi: 10.1111/jop.13054

40. Setterfield J, Theron J, Vaughan RW, Welsh KI, Mallon E, Wojnarowska F, et al. Mucous Membrane Pemphigoid: HLA-DQB1*0301 Is Associated With All Clinical Sites of Involvement and may be Linked to Antibasement Membrane IgG Production. Br J Dermatol (2001) 145:406-14. doi: 10.1046/ j.1365-2133.2001.04380.x

41. Hübner F, Setterfield J, Recke A, Zillikens D, Schmidt E, Dart J, et al. HLA Alleles in British Caucasians With Mucous Membrane Pemphigoid. Eye Lond Engl (2018) 32:1540-1. doi: 10.1038/s41433-018-0092-5

42. Carrozzo M, Fasano ME, Broccoletti R, Carbone M, Cozzani E, Rendine S, et al. HLA-DQB1 Alleles in Italian Patients With Mucous Membrane Pemphigoid Predominantly Affecting the Oral Cavity. Br J Dermatol (2001) 145:805-8. doi: 10.1046/j.1365-2133.2001.04448.x

43. Ujiie $\mathrm{H}$, Muramatsu K, Mushiroda T, Ozeki T, Miyoshi $\mathrm{H}$, Iwata $\mathrm{H}$, et al. HLA-DQB1 ${ }^{*} 03: 01$ as a Biomarker for Genetic Susceptibility to Bullous Pemphigoid Induced by DPP-4 Inhibitors. J Invest Dermatol (2018) 138:1201-4. doi: 10.1016/j.jid.2017.11.023

44. Lindgren O, Varpuluoma O, Tuusa J, Ilonen J, Huilaja L, Kokkonen N, et al. Gliptin-Associated Bullous Pemphigoid and the Expression of Dipeptidyl Peptidase-4/CD26 in Bullous Pemphigoid. Acta Derm Venereol (2019) 99:602-9. doi: 10.2340/00015555-3166

45. McEvoy BP, Montgomery GW, McRae AF, Ripatti S, Perola M, Spector TD, et al. Geographical Structure and Differential Natural Selection Among North European Populations. Genome Res (2009) 19:804-14. doi: 10.1101/ gr.083394.108

46. Khalil I, Lepage V, Douay C, Morin L, al-Daccak R, Wallach D, et al. HLA DQB ${ }^{\star} 0301$ Allele Is Involved in the Susceptibility to Erythema Multiforme. J Invest Dermatol (1991) 97:697-700. doi: 10.1111/1523-1747.ep12484029

47. Lee JE, Reveille JD, Ross MI, Platsoucas CD. HLA-DQB1*0301 Association With Increased Cutaneous Melanoma Risk. Int J Cancer (1994) 59:510-3. doi: 10.1002/ijc.2910590413

48. Lee JE, Lowy AM, Thompson WA, Lu M, Loflin PT, Skibber JM, et al. Association of Gastric Adenocarcinoma With the HLA Class II Gene DQB10301. Gastroenterology (1996) 111:426-32. doi: 10.1053/gast.1996.v111.pm8690208

49. Cuzick J, Terry G, Ho L, Monaghan J, Lopes A, Clarkson P, et al. Association Between High-Risk HPV Types, HLA DRB1* and DQB1* Alleles and Cervical Cancer in British Women. Br J Cancer (2000) 82:1348-52. doi: 10.1054/ bjoc. 1999.1103

50. Lai YC, Yew YW, Lambert WC. Bullous Pemphigoid and its Association With Neurological Diseases: A Systematic Review and Meta-Analysis. J Eur Acad Dermatol Venereol JEADV (2016) 30:2007-15. doi: 10.1111/jdv.13660

51. Amber KT, Zikry J. Hertl M. A Multi-Hit Hypothesis of Bullous Pemphigoid and Associated Neurological Disease: Is HLA-DQB1*03:01, a Potential Link Between Immune Privileged Antigen Exposure and Epitope Spreading? HLA (2017) 89:127-34. doi: 10.1111/tan.12960

52. Sadik CD, Lima AL, Zillikens D. Pemphigoid Gestationis: Toward a Better Understanding of the Etiopathogenesis. Clin Dermatol (2016) 34:378-82. doi: 10.1016/j.clindermatol.2016.02.010

53. Shornick JK, Jenkins RE, Artlett CM, Briggs DC, Welsh KI, Kelly SE, et al. Class II MHC Typing in Pemphigoid Gestationis. Clin Exp Dermatol (1995) 20:123-6. doi: 10.1111/j.1365-2230.1995.tb02668.x

54. Nanda A, Al-Saeed K, Dvorak R, Al-Muzairai I, Al-Sabah H, Al-Arbash M, et al. Clinicopathological Features and HLA Tissue Typing in Pemphigoid Gestationis Patients in Kuwait. Clin Exp Dermatol (2003) 28:301-6. doi: 10.1046/j.1365-2230.2003.01282.x

55. García-González E, Castro-Llamas J, Karchmer S, Zúñiga J, de Oca DM, Ambaz M, et al. Class II Major Histocompatibility Complex Typing Across the Ethnic Barrier in Pemphigoid Gestationis. A Study in Mexicans. Int J Dermatol (1999) 38:46-51. doi: 10.1046/j.1365-4362.1999.00524.x

56. Liao WWP, Arthur JW. Predicting Peptide Binding to Major Histocompatibility Complex Molecules. Autoimmun Rev (2011) 10:469-73. doi: 10.1016/j.autrev.2011.02.003 
57. Lin MS, Fu CL, Giudice GJ, Olague-Marchan M, Lazaro AM, Stastny P, et al. Epitopes Targeted by Bullous Pemphigoid $\mathrm{T}$ Lymphocytes and Autoantibodies Map to the Same Sites on the Bullous Pemphigoid 180 Ectodomain. J Invest Dermatol (2000) 115:955-61. doi: 10.1046/j.15231747.2000.00153.x

58. Hacker-Foegen MK, Zillikens D, Giudice GJ, Lin M-S. T Cell Receptor Gene Usage of BP180-Specific T Lymphocytes From Patients With Bullous Pemphigoid and Pemphigoid Gestationis. Clin Immunol Orlando Fla (2004) 113:179-86. doi: 10.1016/j.clim.2004.08.003

59. Cross M, Smith E, Hoy D, Carmona L, Wolfe F, Vos T, et al. The Global Burden of Rheumatoid Arthritis: Estimates From the Global Burden of Disease 2010 Study. Ann Rheum Dis (2014) 73:1316-22. doi: 10.1136/ annrheumdis-2013-204627

60. Carter EE, Barr SG, Clarke AE. The Global Burden of SLE: Prevalence, Health Disparities and Socioeconomic Impact. Nat Rev Rheumatol (2016) 12:605-20. doi: 10.1038/nrrheum.2016.137

61. Coral-Alvarado P, Pardo AL, Castaño-Rodriguez N, Rojas-Villarraga A, Anaya J-M. Systemic Sclerosis: A World Wide Global Analysis. Clin Rheumatol (2009) 28:757-65. doi: 10.1007/s10067-009-1144-9

62. Michel M. Immune Thrombocytopenic Purpura: Epidemiology and Implications for Patients. Eur J Haematol Suppl (2009) 71:3-7. doi: 10.1111/ j.1600-0609.2008.01206.x

63. Hehir MK, Silvestri NJ. Generalized Myasthenia Gravis: Classification, Clinical Presentation, Natural History, and Epidemiology. Neurol Clin (2018) 36:253-60. doi: 10.1016/j.ncl.2018.01.002
64. McInnes IB, Schett G. The Pathogenesis of Rheumatoid Arthritis. N Engl J Med (2011) 365:2205-19. doi: 10.1056/NEJMra1004965

65. Audia S, Mahévas M, Samson M, Godeau B, Bonnotte B. Pathogenesis of Immune Thrombocytopenia. Autoimmun Rev (2017) 16:620-32. doi: 10.1016/ j.autrev.2017.04.012

66. van Drongelen V, Holoshitz J. Human Leukocyte Antigen-Disease Associations in Rheumatoid Arthritis. Rheum Dis Clin North Am (2017) 43:363-76. doi: 10.1016/j.rdc.2017.04.003

Conflict of Interest: The authors declare that the research was conducted in the absence of any commercial or financial relationships that could be construed as a potential conflict of interest.

Publisher's Note: All claims expressed in this article are solely those of the authors and do not necessarily represent those of their affiliated organizations, or those of the publisher, the editors and the reviewers. Any product that may be evaluated in this article, or claim that may be made by its manufacturer, is not guaranteed or endorsed by the publisher.

Copyright $\odot 2022$ Ahmed, Anwar and Reche. This is an open-access article distributed under the terms of the Creative Commons Attribution License (CC BY). The use, distribution or reproduction in other forums is permitted, provided the original author(s) and the copyright owner(s) are credited and that the original publication in this journal is cited, in accordance with accepted academic practice. No use, distribution or reproduction is permitted which does not comply with these terms. 